\title{
触 New Disease Reports \\ First report of Penicillium polonicum causing storage rots of onion bulbs in Ankara province, Turkey
}

\author{
E. Çakır ${ }^{1 *}$ and S. Maden ${ }^{2}$ \\ ${ }^{1}$ Plant Protection Central Research Institute, Gayret Mah. F. Sultan Mehmet Bul. No 66, P.K 49, Yenimahalle, 06172, \\ Ankara, Turkey; ${ }^{2}$ Ankara University, Agricultural Faculty, Plant Protection Department, Ankara, Turkey
}

*E-mail: emel_cakir@hotmail.com

Received: 07 Aug 2015. Published: 29 Nov 2015.

Onion (Allium cepa) production is one of the most important agricultural crops in Turkey with bulb harvest of 1,904,846 tonnes from an area of 616,324 ha. In 2013 , about $12 \%$ of this onion bulb harvest (approximately 153,478 tonnes) was produced in Ankara province (TUIK, 2013). A majority of the bulb onion production in Ankara is in Polatll, where the crop is stored in more than 80 climatically uncontrolled stores. Five of the stores have a capacity of more than 200,000 tonnes.

Storage rots caused by fungi are a serious problem in these stores and a survey of the five largest stores was conducted at two intervals during December 2014 to determine the causal agents. Blue rot was the most common onion bulb rot symptom observed in these stores (Fig. 1). About $30 \%$ of the fungi, isolated on half-strength potato dextrose agar (PDA) from 143 rotted onion bulb samples, yielded similar blue mould colonies that were identified as a Penicillium species. A majority of these Penicillium isolates showed identical colonies on malt extract agar and PDA (Fig. 2). Microscopic examination of the colonies revealed two-stage branched conidiophores, adpressed phialides with rough-walled stipes (Fig. 3 ) and conidia that were smooth, globose to subglobose, 3-4 $\mu \mathrm{m}$ in diameter (Fig 4). These characteristics were identical with Penicillium polonicum as described by Zaleski (1927) and Frisvard \& Samson (2004). The internal transcribed spacer (ITS) sequences of a representative strain (isolate 8) were compared with related species retrieved from GenBank, resulting in 99\% sequence homology with many accession numbers (e.g. JF731251, JF731260, JF731275) of $P$. polonicum. Our strain, $P$. polonicum isolate 8 was deposited in the culture collection of Ankara Central Plant Protection Institute (Accession No. ZMMAE 8) and the ITS sequence of the isolate was deposited in GenBank (Accession No. KT879913).

Three isolates of $P$. polonicum (isolates 8, 50 and 57) were tested for pathogenicity by inoculating wounded bulb necks of healthy onion. The bulbs were inoculated by injecting $250 \mu \mathrm{l}$ of a conidial suspension $\left(10^{5}\right.$ conidia/ml $)$ in sterile water scraped from a colony grown on PDA. Inoculated bulbs were stored in humid plastic boxes at $18 \pm 2^{\circ} \mathrm{C}$ and disease evaluation was made after 12 days. Six bulbs were used for each isolate. A majority of the inoculated onion bulbs showed rotting starting from the neck (Fig. 5) and two out of the 18 total inoculated bulbs were completely rotted. Symptoms appeared in a week. There was no significant difference in pathogenicity between the three isolates. Isolates recovered from inoculated bulbs showed the same morphological characteristics as the original ones, thus completing Koch's postulates. $P$. polonicum is a fungus with a broad host range including cereals, peanuts, onions, dried meats, citrus fruits and yam tubers (Frisvad \& Samson, 2004) and was recently reported to cause onion rots in Serbia (Duduk et al., 2014) and kiwifruit (Actinidia arguta) rot in China (Wang et al., 2015). To our knowledge, this is the first report of $P$. polonicum on stored onion in Turkey; previously Penicillium spp. were reported as the most common storage rot pathogen but were not identified to species (Özer, 1995).

\section{Acknowledgements}

This work was supported by Turkish Ministry of Agriculture.

\section{References}

TUIK, 2013. Turkish Statistical Institute. Production of vegetables. http://www.tuik.gov.tr/PreTablo.do?alt_id=1001, 30.07.2015

Duduk N, Vasić M, Vico I, 2014. First report of Penicillium polonicum causing blue mold on stored onion (Allium cepa) in Serbia. Plant Disease 98, 1440. http://dx.doi.org/10.1094/PDIS-05-14-0550-PDN

Frisvad JC, Samson RA, 2004. Polyphasic taxonomy of Penicillium subgenus Penicillium. A guide to identification of food and air-borne terverticillate Penicillia and their mycotoxins. Studies In Mycology 49, $1-173$.

Özer N, 1995. [Determination of fungal agents growing on onion bulbs and possibilities of chemical control of them.] In Turkish. Edime, Turkey: Tekirdağ Agricultural Faculty Publications, Trakya Üniversity. Publication No: 226, Research No: 223.

Wang CW, Ai J, Lv HY, Qin HY, Yang YM, Liu YX, Fan ST, 2015. First report of Penicillium expansum causing postharvest decay on stored kiwifruit (Actinidia arguta) in China. Plant Disease 99, 1037. http://dx.doi.org/10.1094/PDIS-12-14-1274-PDN

Zaleski KM, 1927. Über die in Polen gefundenen arten der gruppe Penicillium Link. Bulletin International de l'Académie Polonaise des Sciences et des Lettres Série B 1927, 417-563.

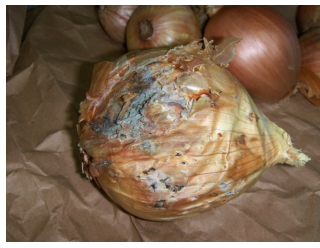

Figure 1

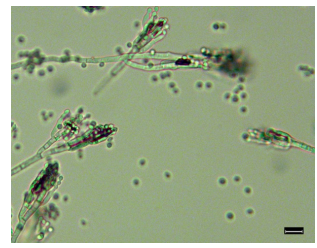

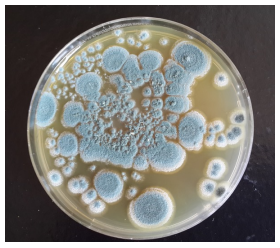

Figure 2

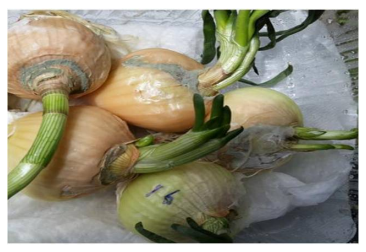

Figure 3

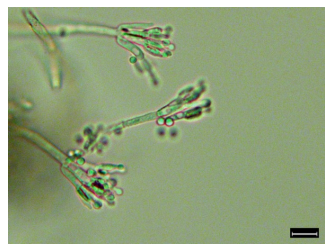

Figure 4

Figure 5

To cite this report: Çakır E, Maden S, 2015. First report of Penicillium polonicum causing storage rots of onion bulbs in Ankara province, Turkey. New Disease Reports 32, 24. http://dx.doi.org/10.5197/j.2044-0588.2015.032.024

(c) 2015 The Authors

This report was published on-line at www.ndrs.org. uk where high quality versions of the figures can be found. 